\title{
Libido Increased, CTCAE
}

National Cancer Institute

\section{Source}

National Cancer Institute. Libido Increased, CT CAE. NCI Thesaurus. Code C143650.

A disorder characterized by an increase in sexual desire. 